\title{
Waste water treatment by exoelectrogenic bacteria isolated from technogenically transformed lands
}

\author{
Svitlana Hnatush ${ }^{1 *}$, Olha Maslovska ${ }^{1}$, Tetyana Sehin ${ }^{1}$, Oresta Vasyliv ${ }^{1}$, \\ Myroslav Kovalchuk ${ }^{2}$, Myroslav Malovanyy ${ }^{3}$
}
${ }^{1}$ Ivan Franko National University of Lviv, Biological Faculty, Department of Microbiology, Hrushevsky Str. 4, Lviv, 79005, Ukraine
${ }^{2}$ LLC “Institute Hirhimprom”, Academy of Mining Sciences of Ukraine 98, Stryjska St., Lviv 79026, Ukraine ${ }^{3}$ Viacheslav Chornovil Institute of Sustainable Development, Lviv Polytechnic National University, S. Bandera Str. 12, Lviv, 79013, Ukraine
"e-mail: gnatuk88@ukr.net

Received: 28 August 2019 / Accepted: 2 December 2019

\begin{abstract}
The capacity of sulfur-reducing bacteria Desulfuromonas acetoxidans IMV B-7384, Geobacter sp. CB35 and Desulfuromusa sp. CB30 and green photosynthesizing bacteria Chlorobium limicola IMV K-8 for exoelectrogenesis was investigated during their growth in wastewater of industrial and municipal origin. The strains of exoelectrogens, which are characterized by resistance to heavy metal ions, were isolated from the man-made Yavorivske lake located in the Lviv Oblast in Ukraine (D. acetoxidans IMV-7384, Ch. limicola IMV K-8) and mine waste heaps of the Chervonohrad mining industry region (Geobacter sp. CB 30 and Desulfuromusa sp. CB 35). Bacteria D. acetoxidans IMB B-7384 proved to be the most effective exoelectrogens. The power density of a microbial fuel cell (MFC) with the application of $D$. acetoxidans IMV B-7384 and the infiltrate of the Lviv solid waste landfill was $2.0 \pm 0.05$ $\mathrm{W} / \mathrm{m}^{2}$ and the reduction of chemical oxygen demand of wastewater was $99 \%$. The new approach to improving the MFC performance was investigated. It includes a combination of phototrophic microorganisms Ch. limicola and heterotrophic microorganisms, which reduce the content of nitrates, nitrites, ammonia, sulfates, sulfites, hydrogen sulfide, while simultaneously generating electric current.
\end{abstract}

Key words: wastewater, bioremediation, microbial fuel cell, bacteria-exoelectrogens.

\section{Introduction}

Wastewater has an energy potential due to the high concentration of bioconversion organic compounds (Do et al., 2018). Among the most polluted waste industries is the waste of alcoholic production plants that characterizes by low $\mathrm{pH}$, high temperature, high ash content, dissolved organic and inorganic substances, high biochemical oxygen demand (BOD) and chemical oxygen demand (COD). High amounts of COD and BOD results in high content of organic compounds, in particular, polysaccharides, reducing sugars, lignin, proteins, melanoidins etc (Kharayat,
2012). Yeast production plants also produce significant amounts of wastewater containing high concentrations of nitrogen compounds (Włodarczyk B \& Włodarczyk P., 2017). Infiltrates of lakes of solid waste landfills are as well the source of chemical and biological environment contamination. It may be compared with the poisonous herbicides by the content of carcinogens (Sereda, 2018). The issues of infiltrates purification of solid waste landfills are considered during design, operation and planned closure of these facilities. The infiltrates of lakes of Lviv solid waste landfills contain heavy metal ions, ammonium compounds, phenol and chlorine, which concentrations 
considerably exceed the maximum permissible limits (Sereda, 2018).

Application of microbial fuel cells (MFC) is promising for bioremediation of wastewater of municipal, domestic or industrial origin with the simultaneous generation of electric current (Do et al., 2018). MFC provides bioconversion of substances with simultaneous formation of electric current (Dowdy et al., 2017). This technology is characterized by the absence of necessity of active sludge excess, which is an advantage over other methods of bioremediation e.g. application of active sludge or methane-tanks (He et al., 2017; Santoro et al., 2017; Gajda et al., 2018). There are known investigations of application of various origins wastewater for electric current generation in an MFC, in particular domestic wastewater, sewage of pig farms, food industry, brewery (Chaturvedi \& Verma, 2016; Tharali et al., 2016). Complex substrates of wastewaters of various origins may cause difficulties for electric current generation by microorganisms-exoelectrogens in comparison with pure substrates, e.g. while use of acetate, butyrate or propionate. In addition, wastewater contains high concentrations of ammonium compounds, heavy metals and other toxic substances that may cause a detrimental effect on microorganism cells (Chaturvedi \& Verma, 2016; Tharali et al., 2016). With the purpose of water and soils bioremediation that are contaminated by heavy metal compounds and other xenobiotics, it is important to use bacteria strains that were isolated from man-made environments and possesses such properties, as psychrotolerance, resistance to high concentrations of hydrogen sulfide, nitrates, nitrites, sulfates, heavy metals and others. The search for strains, which are resistant to the components of wastewaters and capable to electric current generation while bioconversion of these substrates, discovers the new avenues for improvement of MFC technology.

Several groups of bacteria that belong to classes Alfa-, Beta-, Gamma- and Deltaprotebacteria are characterized by exoelectrogenic properties. A significant number of exoelectrogenic strains supports sulfur cycle (Logan, 2009). Sulfur-reducing bacteria Desulfuromonas acetoxidans are among the first investigated microorganisms that possesses exoelectrogenic properties. A characteristic feature of $D$. acetoxidans is their ability to oxidize organic compounds in tricarboxylic acids cycle with simultaneous reduction of extracellular electron acceptors, in particular, Fe (III) ions (Vasyliv, 2013; Maslovscka, 2017). The strain Desulfuromonas acetoxidans IMV B-7384 was isolated from anthropogenouscreated lake Yavorivske as the result of flooding of the sulfur quarry territory (Lviv Oblast, Ukraine). D. acetoxidans IMV B-7384 possesses resistance to the influence of heavy metal ions, in particular, ferrum, cooper, cobalt and nickel in concentrations that exceeds the allowable maximum (Vasyliv, 2013). This bacterium also capable to oxidize organic compounds (acetate, higher fatty acids, propionate and others) with simultaneous sulfur reduction (Gudz et al., 2013). Such properties of D. acetoxidans IMV B-7384 provide its prospect for being used as the effective anode biocatalyst in MFC with simultaneous wastewater pollution control. Isolated from coal pit waste heaps of the mines of Chervonohrad mining region sulfur-reducing bacteria Desulfuromusa sp. CB30 and Geobacter sp. CB35 carry out dissimilatory sulfur-, nitrate-, nitrite- and metalreduction while oxidation of various organic substrates. These strains reduce $\mathrm{Mn}$ (IV), Cr (VI), Cu (II) and Fe (III) and are resistant to $\mathrm{Cr}$ (III)- and $\mathrm{Cr}$ (VI)-compounds (Diakiv et al., 2017). Taking into consideration the physiological and biochemical properties of these strains, we assume that they are capable to exoelectrogenesis. Sulfur-reducing bacteria $D$. acetoxidans are often found in consortium with green photosynthetic bacteria Chlorobium limicola that are also characterized by exoelectrogenic properties (Badalamenti, 2013). Green photosynthetic bacteria Chlorobium limicola IMV K-8 are producers of glycogen (Patent of Ukraine, 2011) and pigments. Produced glycogen as a result of photosynthesis may subsequently be a substrate for electric current generation by exoelectrogenic bacteria.

Therefore the aim of work was to investigate the electric current generation by bacteria-exoelectrogens, which were isolated from technogenically transformed territories, while growth in wastewater of industrial and municipal origin.

\section{Material and methods}

\subsection{Microorganisms}

The ability to exoelectrogenesis of bacteria, which were isolated from technogenically transformed territories, has been investigated while its growth in the infiltrate of Lviv solid waste landfill and in wastewater from the yeast and alcohol production plants. The strains-exoelectrogens were isolated from an anthropogenous-created Yavorivske lake (Lviv Oblast, Ukraine) (Desulfuromonas acetoxidans IMV B-7384, Chlorobium limicola IMV K-8) and coal pit waste heaps of the mines of Chervonohrad mining region (Geobacter sp. CB 30 and Desulfuromusa sp. CB 35) and identified by the staff of Department of Microbiology of Ivan Franko National University of Lviv (Diakiv et al., 2017).

\subsection{Microbial fuel cell}

In this work the one-chamber microbial fuel cell was applied. It consisted of the anode chamber $(50 \mathrm{ml})$ that was inserted into the cathode chamber $(250 \mathrm{ml})$ and 
separated by the proton-exchange membrane (Millipore, pore size: $\left.0.20 \mu \mathrm{m}, 44 \mathrm{~cm}^{2}\right) .0 .1 \%$ solution of $\mathrm{KMnO}_{4}$ was used as the catolyte. As the anolyte bacterial suspensions of D. acetoxidans IMV B-7384, Geobacter sp. CB 30, Desulfuromusa sp. CB 35 and Ch. limicola IMV K-8 at the exponential phase of growth with an initial biomass $0.2 \mathrm{~g} / \mathrm{l}$ were separately applied. Wastewater of various origins, such as yeast factory and alcoholic production plant, and infiltrate of Lviv solid waste landfill, diluted by 10 times with distilled water, were separately added into the MFC anode chamber with the aim to investigate electric current generation by investigated bacteria. Study of exoelectrogenic properties of applied bacteria species at MFC was carried out under anaerobic conditions and temperature $+28 \ldots+30^{\circ} \mathrm{C}$ during $5-15$ days.

\subsection{Measurement of chemical oxygen demand and inorganic compounds content}

COD was determined according to (Wang \& Dong, 2018). $\mathrm{BOD}$ and inorganic compounds content were determined
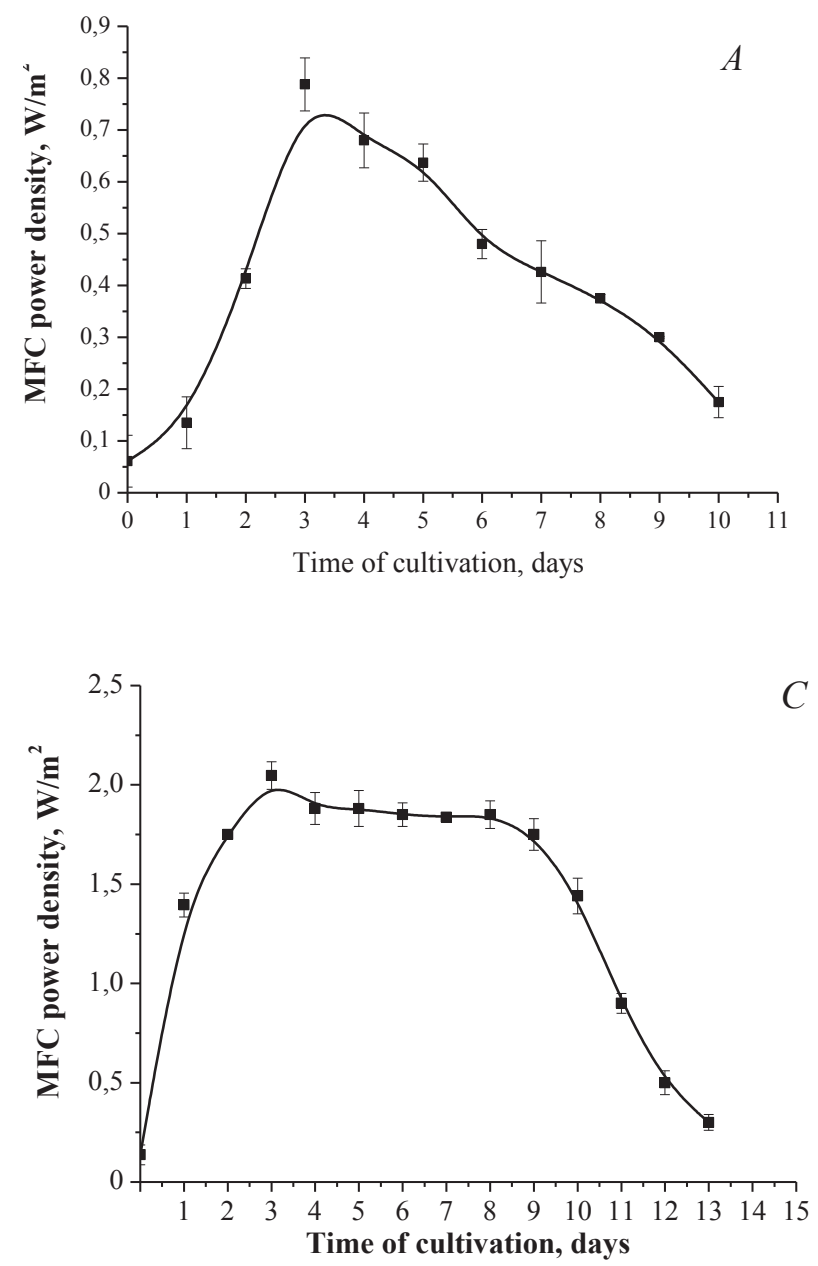

by the method (Methods for chemical analysis of water and wastes, 1983; ISO 17381:2003; Protocol for the Sampling and Analysis Of Industrial/Mmunicipal Wastewater, 2016).

The ability of microorganisms to form a biofilm on the electrode surface was determined by scanning electron microscopy (scanning electron microscope JEOL JSMT220A).

\subsection{Statistic processing of results}

Experiments were repeated three times with three parallel formulations for each variant of experimental and control conditions. The obtained data were processed by generally accepted methods of variation statistics. The reliability of the difference was evaluated by using ANOVA. Differences between the samples were considered reliable at $\mathrm{P}<0.05$.

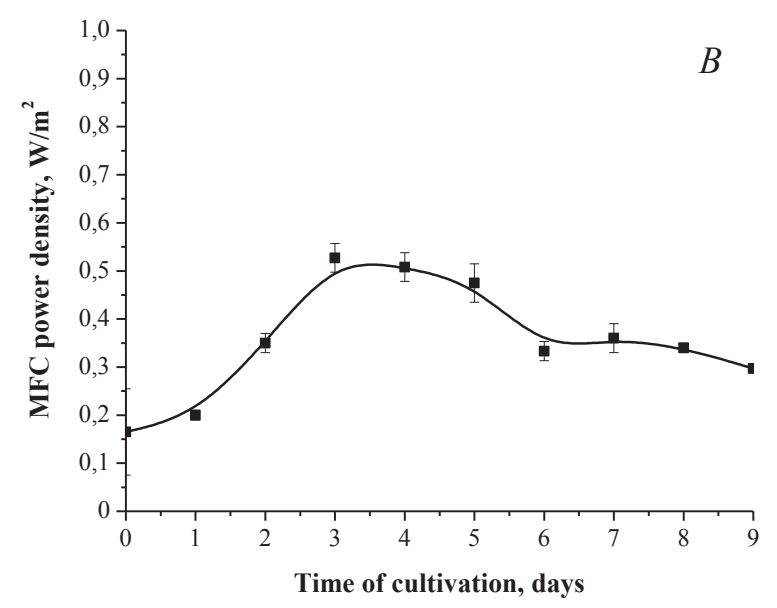

Figure 1. Power density of one-chamber MFC while application as the anode biocatalyst Geobacter sp. CB 35 (A), Desulfuromusa sp. CB 30 (B), D. acetoxidans IMV B-7384 (C) and infiltrate of Lviv solid waste landfill 


\section{Results and discussion}

\subsection{Electric current generation by sulfur-reducing bacteria-exoelectrogenes while growing on infiltrate of solid waste landfill}

It has been determined that Geobacter sp. CB 30, Desulfuromusa sp. CB 35 and D. acetoxidans IMV B-7384 are capable to generate electric current while growth on infiltrate of Lviv solid waste landfill (Fig. 1). The highest MFC power density was observed while application of D. acetoxidans IMV B-7384 bacteria. Its maximum value $\left(2.0 \pm 0.05 \mathrm{~W} / \mathrm{m}^{2}\right)$ was obtained during the third day of bacteria growth. MFC power density slightly decreased with increase of duration of $D$. acetoxidans IMV B-7384 cultivation, but remained stable for 10 days.

Power density of one-chamber MFC while Geobacter sp. CB 35 and Desulfuromusa sp. CB 30 growth on infiltrate of Lviv solid waste landfill was lower by 2.5 and 3.5 times respectively.

\subsection{Electric current generation}

by Desulfuromonas acetoxidans IMV B-7384 while growing on wastewater of yeast production plant

It was determined that $D$. acetoxidans IMV B-7384 is capable to generate electric current in MFC while growth on wastewater of yeast production plant (Fig. 2).

The highest MFC power density was observed on the third day of bacterial cultivation. MFC power density decreased by $26 \%$ compared to maximum value, but was stable during 4-9 days of bacterial cultivation at these conditions.

The chemical composition of wastewater of yeast production plant after incubation in MFC with $D$. acetoxidans IMV B-7384 as the anode biocatalyst has been determined after 12 days of cultivation (Table 1).

The content of organic and inorganic compounds of wastewater of yeast production plant significantly changed after its incubation in MFC with application of $D$. acetoxidans IMV B-7384. The content of $\mathrm{SO}_{4}{ }^{2-}, \mathrm{SO}_{3}{ }^{2-}$, $\mathrm{S}^{0}, \mathrm{NO}_{3}^{-}, \mathrm{NO}_{2}^{-}$and others decreased during twelve days of bacteria incubation. Since D. acetoxidans IMV B-7384 are sulfur-reducing microorganisms, therefore decrease of $\mathrm{S}^{0}$ content was probably due to the process of sulfurreduction carried out by these bacteria. It is known that D. acetoxidans IMV B-7384 do not use $\mathrm{SO}_{4}{ }^{2-}$ and $\mathrm{SO}_{3}{ }^{2-}$ as electron acceptors during dissimilatory sulfate-reduction (Vasyliv, 2013). Further studies are needed to determine the biochemical processes that cause decrease of these anions content in wastewater of yeast production plant after D. acetoxidans IMV B-7384 incubation in MFC. However, we assume that D. acetoxidans IMV B-7384 can use $\mathrm{SO}_{4}{ }^{2-}$ and $\mathrm{SO}_{3}{ }^{2-}$ in the process of assimilatory sulfurreduction.

Significant decrease in $\mathrm{NO}_{3}{ }^{-}$and $\mathrm{NO}_{2}{ }^{-}$content may occur as the result of nitrate or nitrite respiration carried out by these bacteria. Also, $\mathrm{NO}_{3}{ }^{-}$and $\mathrm{NO}_{2}{ }^{-}$may be assimilated by bacteria D. acetoxidans IMV B-7384 in the processes of assimilatory nitrate- and nitrite-reduction.

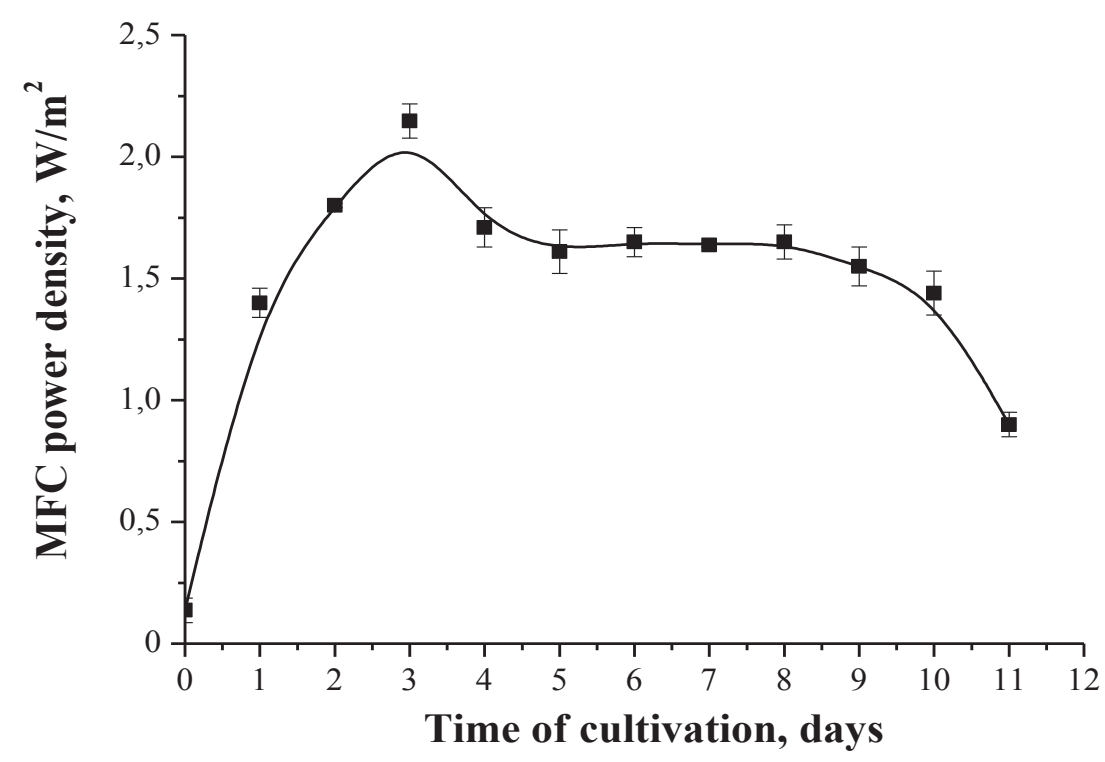

Figure 2. Power density of one-chamber MFC while application of D. acetoxidans IMV B-7384 as the anode biocatalyst and wastewater of yeast production plant 
Table 1. The content of wastewater of yeast production plant after D. acetoxidans IMV B-7384 cultivation in MFC

\begin{tabular}{|c|c|c|}
\hline \multirow{2}{*}{ Index } & \multicolumn{2}{|c|}{ Content of wastewater compounds, g/l } \\
\hline & before cultivation & after cultivation \\
\hline $\mathrm{HCO}_{3}^{-}$ & $9.8 \pm 0.4$ & $14.6 \pm 0.2$ \\
\hline $\mathrm{CO}_{3}^{2-}$ & $9.6 \pm 0.03$ & $7.4 \pm 0.02$ \\
\hline $\mathrm{Mg}^{2+}$ & $7.3 \pm 0.3$ & $0.9 \pm 0.04$ \\
\hline $\mathrm{SO}_{4}^{2-}$ & $30.3 \pm 0.6$ & $2.8 \pm 0.1$ \\
\hline $\mathrm{SO}_{3}^{2-}$ & $25.9 \pm 0.5$ & $2.4 \pm 0.1$ \\
\hline $\mathrm{S}^{0}$ & $20.2 \pm 0.5$ & $1.8 \pm 0.02$ \\
\hline $\mathrm{H}_{2} \mathrm{~S}$ & $21.5 \pm 0.4$ & $1.0 \pm 0.02$ \\
\hline $\mathrm{NO}_{3}^{-}$ & $2.7 \pm 0.02$ & $1.3 \pm 0.02$ \\
\hline $\mathrm{NO}_{2}^{-}$ & $2.0 \pm 0.03$ & $0.9 \pm 0.01$ \\
\hline $\mathrm{P}_{2} \mathrm{O}_{5}$ & $1.1 \pm 0.03$ & $1.7 \pm 0.02$ \\
\hline $\mathrm{PO}_{4}^{3-}$ & $0.8 \pm 0.01$ & $1.2 \pm 0.01$ \\
\hline $\mathrm{P}_{\mathrm{i}}$ & $0.2 \pm 0.01$ & $0.4 \pm 0.01$ \\
\hline $\mathrm{NH}_{4}^{-}$ & $0.5 \pm 0.01$ & $1.7 \pm 0.02$ \\
\hline $\mathrm{Fe}^{2+}$ & $0.006 \pm 0.0001$ & $0.016 \pm 0.001$ \\
\hline $\mathrm{Fe}^{3+}$ & $0.004 \pm 0.0001$ & $0.066 \pm 0.002$ \\
\hline Organics content, $\%$ & $78.4 \pm 0.4$ & $25.6 \pm 0.3$ \\
\hline Conductivity, $\mathrm{mS}$ & $46 \pm 0.2$ & $66 \pm 0.8$ \\
\hline Dry residue & $128.0 \pm 0.4$ & $63.0 \pm 0.3$ \\
\hline $\mathrm{COD}, \mathrm{g} \mathrm{O}_{2} / 1$ & $240.0 \pm 0.4$ & $1.2 \pm 0.04$ \\
\hline $\mathrm{BOD}, \mathrm{mg} \mathrm{O}_{2} / 1$ & $40.0 \pm 0.4$ & $7.2 \pm 0.02$ \\
\hline
\end{tabular}

The electrical conductivity of wastewater significantly decreased after its incubation in MFC, which probably indicates on decrease of organic and inorganic substances content. Important indicators of wastewater indices are COD, BOD and total organic compounds content. After D. acetoxidans IMV B-7384 cultivation in MFC with wastewater of yeast production plant COD decreased by 200 times, BOD by 5.5 times, and organic compounds content decreased by 3 times. At these conditions the content of $\mathrm{HCO}_{3}^{-} / \mathrm{CO}_{3}^{2-}$ significantly increased, which probably indicates on complete oxidation of organic compounds by investigated bacteria.

The increase of electric current value while reduction of organic compounds content during growth of $D$. acetoxidans IMV B-7384 bacteria probably indicates on oxidation of organic matter to $\mathrm{CO}_{2}$. As the result released electrons are transported to the electrode of MFC, which is the final electron acceptor.

Three pathways by which electrons are transferred to an electrode are known so far. They include transport by artificial mediators, by endogenous microorganism mediators and by direct contact with the electrode surface (Shrivastava \& Bundela, 2013). D. acetoxidans IMV B-7384 formed biofilm on the electrode surface while growing on wastewater of yeast production plant in MFC (Fig. 3). Formation of biofilm by D. acetoxidans IMV B-7384 bacteria may cause electrons transfer by cytochromes from reduced equivalents to the electrode surface in MFC. 


\subsection{Application of green photosynthesis bacteria for electric current generation while growing \\ in wastewater}

Anoxygenic phototropic bacteria cause a major role in functioning of biogeochemical cycles and provides transformation of light energy into chemical energy in the process of photosynthesis. Photosynthetic MFC is promising biotechnology that shows avenues in purification of contaminated areas with simultaneous electric current generation (Badalamenti, 2014; Qi et al., 2018). The ability to generate electric current by $\mathrm{Ch}$. limicola IMV K-8 bacterium was investigated. These bacteria were cultivated in MFC on GSB medium, which contained $\mathrm{Na}_{2} \mathrm{CO}_{3}$ as a source of $\mathrm{CO}_{2}$, sodium pyruvate and sodium acetate as additional sources of carbon. As a result of carried out research it was determined that the maximum MFC power density was $1.2 \pm 0.07 \mathrm{~W} / \mathrm{m}^{2}$ on the seventh day of $C h$. limicola IMV K-8 cultivation (Fig. 4). The maximum value of electric current was observed from sixth to eighth days of investigated bacteria cultivation. MFC power density equaled $0.90 \pm 0.05 \mathrm{~W} / \mathrm{m}^{2}$ on the eighth day of Ch. limicola IMV K-8 cultivation in MFC and gradually decreased with an increase of cultivation duration.

It is known that $C$. limicola IMV K-8 are photosynthetic bacteria that are capable to glycogen synthesis at the presence of light (Patent of Ukraine, 2011). Synthesized glycogen by Ch. limicola IMV K-8 while photosynthesis is hydrolyzed to glucose at the absence of light and can be metabolized to acetate, which may serve as a substrate for exoelectrogenic bacteria. Ch. limicola IMV K-8 bacteria were grown during 20 days on the wastewater of yeast production plant. Then Geobacter CB35 with primary biomass $0.3 \mathrm{~g} / \mathrm{l}$ was added to obtained Ch. limicola IMV K-8 bacterial culture. Obtained co-culture together with the wastewater of yeast production plant was added into the anode chamber of MFC. Generated power density equaled $0.95 \pm 0.05 \mathrm{~W} / \mathrm{m}^{2}$ after 2 days of co-culture growth. It's value decreased while further cultivation, however, on the seventh day of growth it increased up to $0.92-0.95 \mathrm{~W} / \mathrm{m}^{2}$ and remained stable for the next two days. We assume that $C h$. limicola IMV K-8 bacteria and Geobacter CB35 oxidize available organic compounds contained in wastewater during six days of growth. The hydrolysis of glycogen, which was accumulated during the photosynthesis of Ch. limicola IMV K-8, occured when content of these compounds reduced. Obtained results require more detailed further investigation and, in particular, determination the glycogen concentration in the cells of investigated bacteria.

We assume that $C h$. limicola bacteria IMV K-8 are able to metabolize compounds contained in wastewater
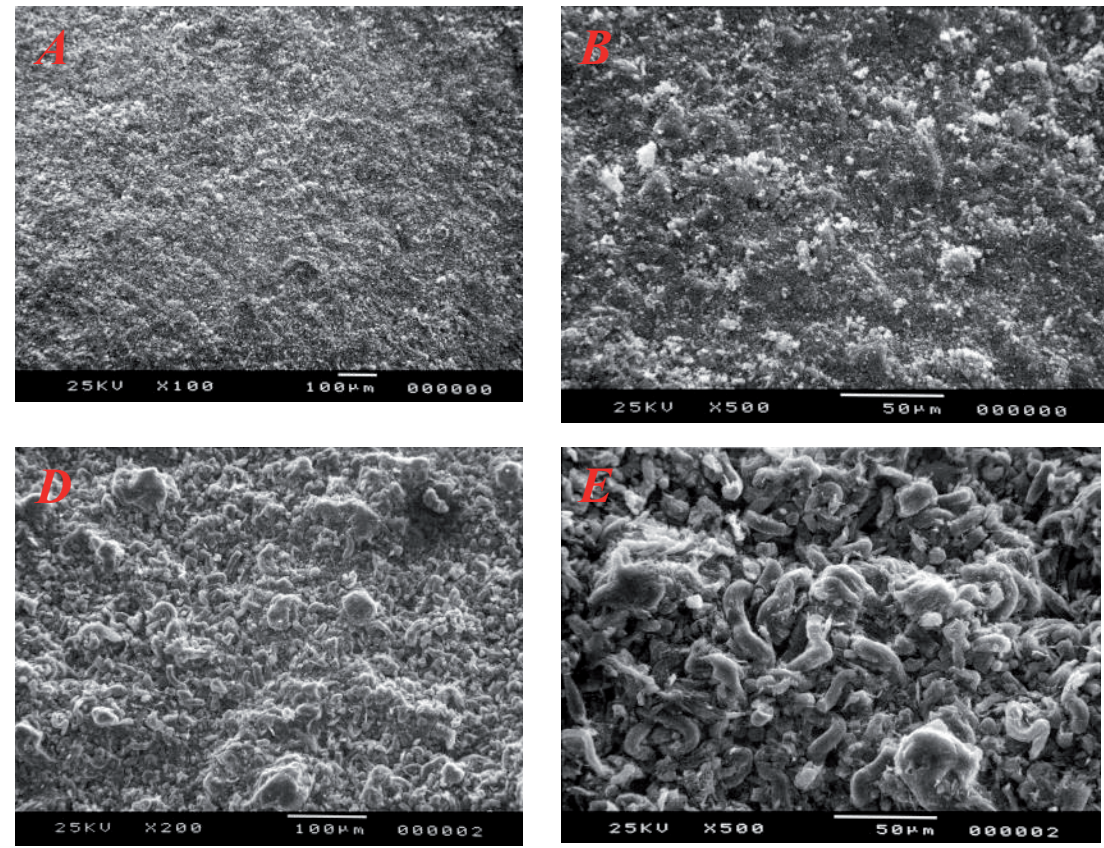
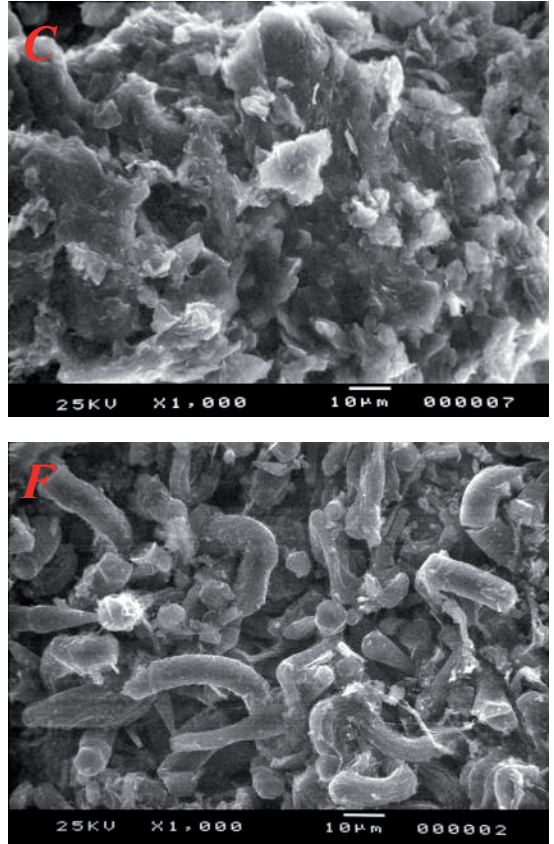

Figure 3. Biofilm formation by D. acetoxidans IMV B-7384 bacteria on the electrode surface in MFC while growth on yeast production plant wastewater (A, B, C - electrode surface before bacteria cultivation in MFC anode chamber; D, E, F- electrode surface after 10 days of bacteria cultivation in MFC) 

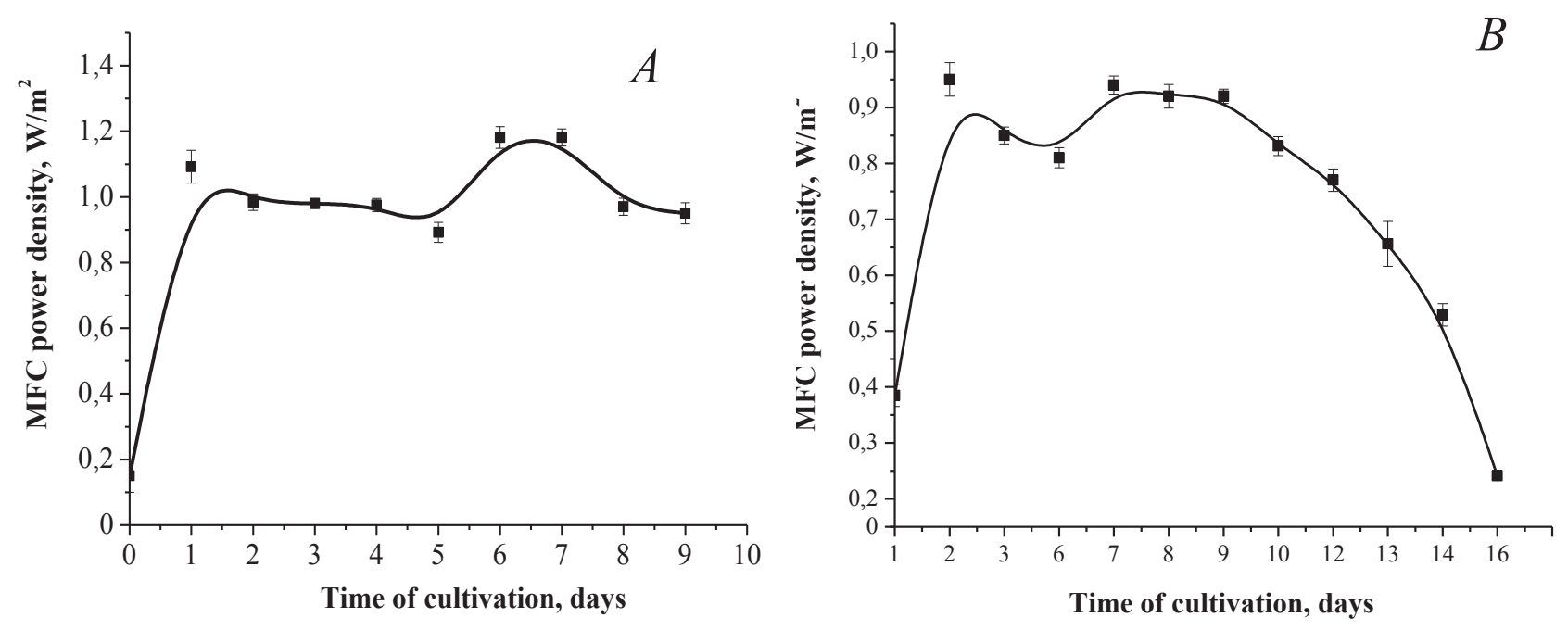

Figure 4. Power density of one-chamber MFC during ten days of Ch. limicola IMV K-8 cultivation while growing on GSB medium (A) and while co-cultivation of Ch. limicola IMV K-8 and Geobacter CB35 with addition of wastewater of yeast production plant (B)

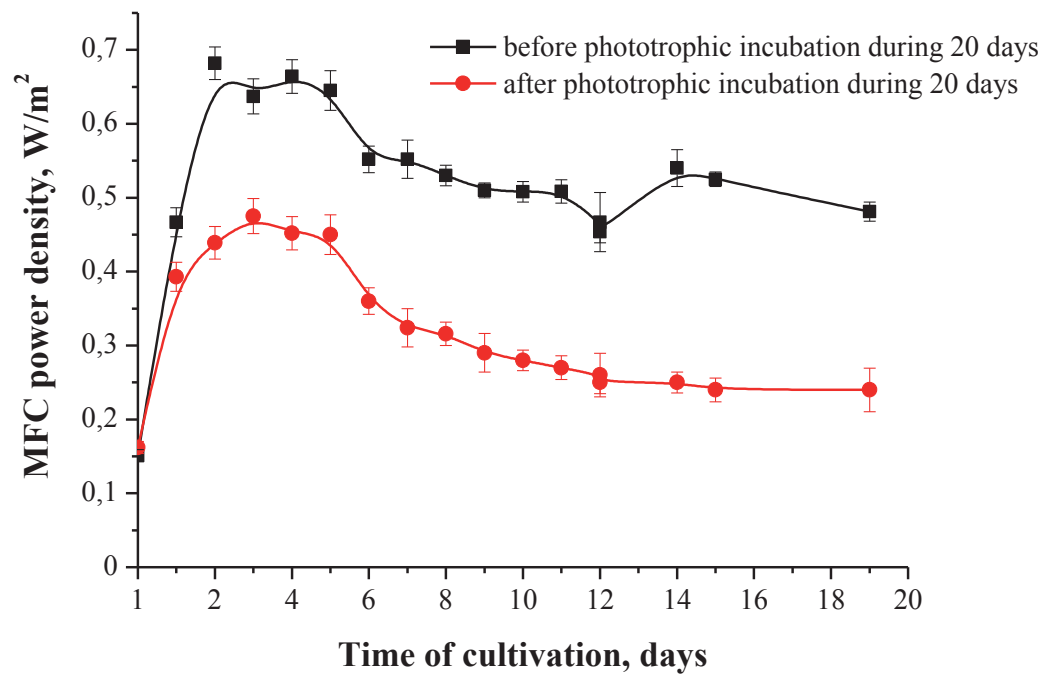

Figure 5. Power density of one-chamber MFC while Ch. limicola IMV K-8 cultivation with wastewater of alcohol plant

of alcohol plant and as a result cause it's bioremediation. Electric current generation has been determined while Ch. limicola IMV K-8 growing on wastewater of alcohol plant and after 20 days of cultivation at phototropic conditions (Fig. 5).

Power density of MFC reaches it's maximum $\left(0.68 \pm 0.02 \mathrm{~W} / \mathrm{m}^{2}\right)$ during second day of $C h$. limicola IMV K-8 bacterium cultivation with waste water of alcohol plant and it was stabile during next five days. MFC power density decreased at sixth day by $24 \%$ in comparison with the maximal obtained value. Power density of MFC decreased with further Ch. limicola IMV K-8 bacterium cultivation.

The power density of MFC while adding into the anode chamber waste water of alcohol plant and Ch. limicola IMV K-8 cells after 20 days of cultivation at phototropic conditions was lower by 1.5 times during the whole time of cultivation in comparison with obtained values while 
adding waste water that was not incubated with $C h$. limicola IMV K-8 before. We assume that bacteria Ch. limicola IMV K-8 metabolized available substances from waste water while phototropic cultivation during twenty days. Therefore the value of generated electric current was lower in comparison with application of waste water, in which Ch. limicola IMV K-8 was not incubated before.

The content of compounds in the wastewater of alcohol plant after 20 days of phototrophic growth of Ch. limicola IMV K-8, 20 days of its heterotrophic growth, and after 20 days of its growth in the anode chamber of MFC has been investigated (Table 2).

It was determined that during phototrophic and heterotrophic growth, as well as while prolonged growth in the anode chamber of MFC, bacteria oxidize organic compounds that results in increase of $\mathrm{HCO}_{3}{ }^{-} / \mathrm{CO}_{3}{ }^{2-}$ con- tent. After Ch. limicola IMV K-8 cultivation in wastewater of alcohol plant COD decreased by 3.5-7.5 times We assume that at the excess of organic matter in wastewater the dominant process in Ch. limicola IMV K-8 cells was catabolism of organic substances in glycolytic or pentose phosphate pathways resulting in $\mathrm{CO}_{3}{ }^{2-}$ formation. $\mathrm{H}_{2} \mathrm{~S}$ content, which is one of the major electron donors for these bacteria during photosynthesis, is also significantly reduced. We assume that at these conditions, processes of photosynthesis may occur, however, with reduced intensity. $\mathrm{H}_{2} \mathrm{~S}$ may also be utilized by $C h$. limicola IMV K-8 bacteria in the processes of assimilatory sulfur-reduction. During bacteria growth in the wastewater of alcohol plant, the content of $\mathrm{SO}_{4}{ }^{2-}, \mathrm{SO}_{3}{ }^{2-}$ and $\mathrm{S}^{0}$ decreases. We assume that these compounds may also be substrates for assimilative sulfur-reduction.

Table 2. Content of waste water of alcohol plant before and after Ch. limicola IMV K-8 cultivation

\begin{tabular}{|c|c|c|c|c|c|}
\hline \multirow[b]{2}{*}{ Index } & \multicolumn{5}{|c|}{ Content of compounds, g/l } \\
\hline & $\begin{array}{c}\text { Before bacteria } \\
\text { cultivation }\end{array}$ & $\begin{array}{l}\text { After } 20 \text { days } \\
\text { of phototrophic } \\
\text { bacteria growth }\end{array}$ & $\begin{array}{l}\text { After } 20 \text { days } \\
\text { of heterotrophic } \\
\text { bacteria growth }\end{array}$ & $\begin{array}{l}\text { After } 20 \text { days } \\
\text { of bacteria } \\
\text { growth in the } \\
\text { anode chamber } \\
\text { of MFC }\end{array}$ & $\begin{array}{c}\text { After } 20 \text { days } \\
\text { of bacteria } \\
\text { phototrophic growth } \\
\text { and } 20 \text { days of growth } \\
\text { in the anode chamber } \\
\text { of MFC }\end{array}$ \\
\hline $\mathrm{HCO}_{3}^{2-}$ & $13.4 \pm 0.64$ & $31.7 \pm 1.59$ & $35.4 \pm 1.81$ & $37.1 \pm 1.86$ & $24.4 \pm 1.18$ \\
\hline $\mathrm{CO}_{3}^{2-}$ & $6.8 \pm 0.31$ & $16.1 \pm 0.73$ & $18.0 \pm 0.77$ & $18.8 \pm 0.91$ & $12.4 \pm 0.48$ \\
\hline $\mathrm{Ca}^{2+}$ & $9.3 \pm 0.44$ & $6.0 \pm 0.25$ & $8.0 \pm 0.31$ & $6.3 \pm 0.34$ & $8.0 \pm 0.39$ \\
\hline $\mathrm{Mg}^{2+}$ & $6.5 \pm 0.33$ & $2.4 \pm 0.12$ & $2.4 \pm 0.12$ & $1.5 \pm 0.07$ & $4.3 \pm 0.22$ \\
\hline $\mathrm{Cl}$ & $10.9 \pm 0.47$ & $12.9 \pm 0.92$ & $10.3 \pm 0.46$ & $14.2 \pm 0.68$ & $8.6 \pm 0.42$ \\
\hline $\mathrm{Na}^{+}$ & $10.1 \pm 0.55$ & $8.4 \pm 0.39$ & $6.7 \pm 0.29$ & $9.2 \pm 0.54$ & $5.6 \pm 0.27$ \\
\hline $\mathrm{K}^{+}$ & $1.9 \pm 0.09$ & $2.8 \pm 0.13$ & $2.2 \pm 0.09$ & $3.1 \pm 0.12$ & $1.9 \pm 0.07$ \\
\hline $\mathrm{SO}_{4}^{2-}$ & $28.6 \pm 1.26$ & $18.1 \pm 0.91$ & $18.6 \pm 0.89$ & $16.4 \pm 0.59$ & $268.2 \pm 13.2$ \\
\hline $\mathrm{SO}_{3}^{2-}$ & $23.8 \pm 1.19$ & $15.5 \pm 0.67$ & $15.9 \pm 0.69$ & $14.0 \pm 0.51$ & $229.0 \pm 10.76$ \\
\hline $\mathrm{S}^{0}$ & $19.1 \pm 0.92$ & $12.1 \pm 0.61$ & $12.4 \pm 0.65$ & $10.9 \pm 0.48$ & $178.7 \pm 9.89$ \\
\hline $\mathrm{H}_{2} \mathrm{~S}$ & $39.2 \pm 1.96$ & $12.8 \pm 0.59$ & $13.2 \pm 0.67$ & $11.6 \pm 0.52$ & $189.9 \pm 8.47$ \\
\hline $\mathrm{NO}_{3}^{-}$ & $5.0 \pm 0.28$ & $1.8 \pm 0.09$ & $0.8 \pm 0.04$ & $0.4 \pm 0.02$ & $2.0 \pm 0.08$ \\
\hline $\mathrm{NO}_{2}^{-}$ & $3.7 \pm 0.18$ & $1.3 \pm 0.06$ & $0.6 \pm 0.03$ & $0.3 \pm 0.01$ & $1.5 \pm 0.07$ \\
\hline $\mathrm{NH}_{4}^{+}$ & $3.2 \pm 0.13$ & $2.7 \pm 0.14$ & $2.5 \pm 0.12$ & $0.2 \pm 0.01$ & $1.5 \pm 0.07$ \\
\hline $\mathrm{P}_{2} \mathrm{O}_{5}$ & $7.3 \pm 0.34$ & $8.2 \pm 0.39$ & $8.2 \pm 0.38$ & $4.2 \pm 0.21$ & $4.4 \pm 0.21$ \\
\hline $\mathrm{PO}_{4}^{3-}$ & $4.9 \pm 0.24$ & $5.5 \pm 0.27$ & $5.5 \pm 0.27$ & $2.8 \pm 0.14$ & $2.9 \pm 0.14$ \\
\hline $\mathrm{P}_{\mathrm{i}}$ & $1.6 \pm 0.11$ & $1.8 \pm 0.07$ & $1.8 \pm 0.09$ & $0.9 \pm 0.08$ & $0.9 \pm 0.06$ \\
\hline $\mathrm{COD} \mathrm{g} \mathrm{O}_{2} / 1$ & $3172 \pm 18$ & $423 \pm 9$ & $634 \pm 11$ & $846 \pm 9$ & $646 \pm 9$ \\
\hline
\end{tabular}


Decrease of the content of $\mathrm{NO}_{3}^{-}, \mathrm{NO}_{2}^{-}$and $\mathrm{NH}_{4}^{+}$ions was observed while $C h$. limicola IMV K-8 growth in wastewater. $\mathrm{NH}_{4}^{+}$is known to be a source of nitrogen for Ch. limicola IMV K-8 therefore its elimination may be a result of its assimilation (Moroz \& Rusyn, 2012). It was determined that $C h$. limicola IMV K-8 does not use $\mathrm{NO}_{3}^{-}$and $\mathrm{NO}_{2}^{-}$as the source of nitrogen. These ions inhibit metabolism of nitrogen in ammonium form, growth and photoassimilation of $\mathrm{H}_{2} \mathrm{~S}$ in comparison with control (Moroz \& Rusyn, 2012). However, the genes whose products are involved in assimilatory and dissimilatory nitrate reduction and denitrification have been identified in the genome of green photosynthetic bacteria Chlorobium phaeovibrioides (https://www.genome.jp/kegg-bin/show pathway?pvi00910). We assume that $C h$. limicola IMV $\mathrm{K}-8$ cells adapt and metabolize $\mathrm{NO}_{3}{ }^{-}$and $\mathrm{NO}_{2}{ }^{-}$while growth on wastewater of alcohol plan.

The content of $\mathrm{P}_{2} \mathrm{O}_{5}, \mathrm{PO}_{4}^{3-}$, and $\mathrm{P}_{\mathrm{i}}$ significantly reduced while wastewater incubation in MFC. The content of these compounds in wastewater after phototrophic or heterotrophic growth of $\mathrm{Ch}$. limicola IMV K-8 was higher in comparison with the primary value. We assume that changes of the phosphorus compounds content in wastewater are dependant on metabolic processes of Ch. limicola IMV K-8 bacteria.

Further studies are needed to investigate more detailed causes of changes of wastewater content of alcohol plant while $C h$. limicola IMV K-8 bacteria growth. Understanding the metabolism processes of organic compounds, sulfates, nitrates, phosphates will allow to create optimal conditions for bioremediation of wastewater of industrial origin, in particular, wastewater of alcohol plants.

Hence green photosynthetic bacteria Ch. limicola IMV K-8 oxidize organic compounds with simulatneous electric current generation while growth on waste water as the carbon source. Also these bacteria metabolize sulfates, nitrates and phosphates and therefore support wastewater bioremediation.

\section{Conclusions}

Bacteria-exoelectrogens, which were isolated from technogenically transformed territories, are able to generate electric current while growth on wastewater of industrial or municipal origin with its simulataneous bioremediation. The most effective exoelectrogen was D. acetoxidans IMV B-7384 bacterium among investigated strains. It was determined that biofilm formation on the surface of the electrode is crucial for electric current generation by bacteria. Probably D. acetoxidans IMV B-7384 bacteria are capable to oxidize much wider range of organic compounds and are more resistant to the influence of toxic compounds in comparison with Geobacter sp. CB35 and Desulfuromusa sp. CB30.
Application of the consortium of phototrophic and heterotrophic microorganisms in MFC is an effective approach to wastewater treatment that provides elimination of pollution by organics, nitrates, nitrites, ammonium, sulfates, sulfites and others with simultaneous generation of electric current.

\section{References}

Badalamenti J., 2013, Coupling dark metabolism to electricity generation using photosynthetic cocultures. Biotechnology and Bioengineering 111(2): 223-31.

Chaturvedi V. \& Verma P., 2016, Microbial fuel cell: a green approach for the utilization of waste for the generation of bioelectricity. Bioresources and Bioprocessing 3: 38 . (https://doi.org/10.1186/s40643-016-0116-6).

Do M., Ngo H., Guo W., Liu Y., Chang S.W., Nguyen D.D., Nghiem L.D. \& Ni B.J., 2018, Challenges in the application of microbial fuel cells to wastewater treatment and energy production: a mini review. Science of the Total Environment 639: 910-920.

Dowdy F., Kawakita R., Lange M. \& Simmons C., 2017, Meta-analysis of microbial fuel cells using waste substrates. Applied Biochemistry and Biotechnology 185(1): 221-232.

Diakiv S., Hnatush S. \& Moroz O., 2016, Sulfur reducing bacteria from coal pits waste heaps of Chervonograd minig region. Studia Biologica 10(2): 63-76.

Gajda I., Greenman J. \& Ieropoulos I., 2018, Review article recent advancements in real-world microbial fuel cell applications. Current Opinion in Electrochemistry 11: 78-83.

Gudz S., Hnatush S., Moroz O. Peretiatko, T. \& Vasyliv, O., 2013, Certificate of deposition of strain of bacteria Desulfuromonas acetoxidans Ya-2006 in the Depository of Institute of Microbiology and Virology, NAS of Ukraine on granting registration number IMV B-7384 of 10 April 2013.

He L., Du P., Chen Y., Lu H., Cheng X., Chang B. \& Wang Z., 2017, Advances in microbial fuel cells for wastewater treatment. Renewable and Sustainable Energy Reviews $71: 388-403$.

ISO 17381:2003 Water quality - Selection and application of ready-to-use test kit methods in water analysis.

Kharayat Y., 2012, Distillery wastewater: bioremediation approaches. Journal of Integrative Environmental Sciences 9(2): 69-91.

Logan B., 2009, Exoelectrogenic bacteria that power microbial fuel cells. Nature Reviews Microbiology 7: 375-381.

Maslovscka O., 2017, Antioxidant defense and fatty acid composition of Desulfuromonas acetoxidans IMV B-7384 under the influence of ferric (III) citrate. Ph.D. 
Thesis, D. K. Zabolotny Institute of Microbiology and Virology, NAS of Ukraine, Kyiv.

Methods for chemical analysis of water and wastes, 1983, U.S. Environmental Protection Agency, Office of Research and Development, Washington, DC 20460, 491 pp.

Moroz O. \& Rusyn I., 2012, Usage of nitrogen compounds by sulfur cycle bacteria of Yavorivske Lake. Microbiology and Biotechnology 2: 96-108.

Qi X., Ren Y., Liang P. \& Wang X., 2018, New insights in photosynthetic microbial fuel cell using anoxygenic phototrophic bacteria. Bioresource Technology 258: 310-317.

Patent of Ukraine, 2011, MPK N01M8/00; N01M 8/16; N01M 8/22. Consortium of Chlorobium limicola Ya2002 and Pseudomonas sp. - producer of glycogen / Gorishnyi M.B., Gudz S.P., Moroz O. M., Hnatush S. O., Levytska O.; applicant and owner is Ivan Franko National University of Lviv. - No. 63723; stated on 25.11.2011.

Protocol for the Sampling and Analysis Of Industrial/ Municipal Wastewater. Version: 2.0, 2016, Ontario Ministry of the Environment and Climate Change, Laboratory Services Branch, Ontario, 195 pp.

Santoro C., Arbizzani C. \& Erable B., 2017, Microbial fuel cells: From fundamentals to applications. A review. Journal of Power Sources 356: 225-244.
Sereda A., 2018, Two-stage purification of landfill infiltrates in aerobic lagoons and municipal wastewater treatment facilities. Ph.D. Thesis, Lviv Polytechnic National University Ministry of Education and Science of Ukraine, Lviv.

Shrivastava S. \& Bundela H., 2013, Power generation through double chamber MFC operation by slurry mixed with different substrates. International Journal Engineering Trends and Technology 4: 4201-4205.

Tharali A., Sain N. \& Osborne W., 2016, Microbial fuel cells in bioelectricity production. Frontiers in Life Science 9(4): 252-266.

Vasyliv O., 2013, The influence of 3d-type transition metals on physiological and biochemical properties of $\mathrm{De}$ sulfuromonas acetoxidans bacteria. Ph.D. Thesis, D. K. Zabolotny Institute of Microbiology and Virology, NAS of Ukraine, Kyiv.

Wang J.-P. \& Dong Q.-H., 2018, Analysis and discussion on the calculation formula of the classical monitoring method of the permanganates index $\left(\mathrm{I}_{\mathrm{Mn}}\right)$. Journal of Education and Practice 9(22): 1-4.

Włodarczyk B. \& Włodarczyk P., 2017, Microbial fuel cell with $\mathrm{Cu}-\mathrm{B}$ cathode powering with wastewater from yeast production. Journal of Ecological Engineering 18(4): 224-230.

https://www.genome.jp/kegg-bin/show_pathway?pvi00910. 